\title{
Berlinale 2001 Report
}

\author{
By Ron Holloway \\ Spring 2001 Issue of KINEMA
}

INTERNATIONAL FILM FESTIVAL BERLIN 2001

IT fit the 2001 Berlinale (7-18 February 2001) like a glove: Stanley Kubrick's 2001 -- A Space Odyssey as the closing night presentation. For back at the 1981 Berlinale, when Martin Scorsese delivered a fiery, passionate lecture on "Color Fading," he cited 2001 in particular to underscore the dilemma of colour preservation. Thanks to his efforts, and those of dedicated film archivists, Stanley Kubrick's 2001: A Space Odyssey (1968) has now been restored to its original pristine colour photography -and was the undeniable hit of the Berlinale.

When one recalls that Berlinale director Alfred Bauer had laboured far into the night to book Kubrick's 2001 for the 1968 festival -- a failed effort now fulfilled -- this made for a particularly poignant evening. Stanley Kubrick's widow attended the screening, together with his brother-in-law Jan Harlan, whose documentary Stanley Kubrick: A Life in Pictures was programmed as part of the tribute. And since Kirk Douglas was also being honoured with a festival homage, Kubrick's Paths of Glory (1957) was equally well received at its special screening in the Berlinale Palast on Marlene-Dietrich-Platz.

Surely the 51st Berlinale will be long remembered for its splendid Fritz Lang retrospective, the accompanying exhibition in the recently opened Filmmuseum Berlin, and the Special Screening of his classic Metropolis (Germany, 1925/26). Indeed, sellout crowds enthusiastically applauded the screenings, the silent films were shown with live musical accompaniment, the "FL" catalogue runs 512 pages, and the exhibition is now scheduled to go on tour -- to Vienna, Paris, Los Angeles, and San Francisco.

Like many popular film classics, Fritz Lang's Metropolis begs credibility in theme and content. "Quite the silliest film made," said H.G. Wells. "One of the greatest insanities ever perpetrated in the world of cinema," seconded Pauline Kael, "although not so great as Intolerance, but in some ways even more insane." Lang himself shared their opinion but with reservations: "When we cut out all the magic, I had the feeling that Metropolis was patched together." What interested Lang in particular was the machinery involved and the opportunity to experiment.

"Fritz Lang was a master of lighting," wrote Lotte Eisner. "In Metropolis the futuristic city appears as a superb pyramidal accumulation of shimmering sky-scrapers. The light seems to explode, spreading a luminous mist, falling as iridescent rain." Then there was Eugen Schüfftan's "mirror reflection technique," or the so-called "Schüfftan process," an optical trick shot that made the streets and bridges of the city appear huge on the screen. Add to this the restored black-and-white print, the new musical score by Bernd Schultheis, the orchestral accompaniment by the Berlin Radio Symphony Orchestra under the baton of Frank Strobel, and you have a presentation of a masterpiece you won't soon forget.

The Berlinale opened with Jean-Jacques Annaud's Enemy at the Gates, an international coproduction shot in English at Studio Babelsberg and on location in Brandenburg. However, since Duell -- Enemy at the Gates (the German title) depicted the naked horror of war at the Battle of Stalingrad in 1942, the unruly echo from critics and public was partially justified. Nevertheless, the production's extraordinary range of special effects and Studio Babelsberg's overall display of technical know-how was an appropriate answer to Steven Spielberg's cinematic conception of the Normandy Invasion in Saving Private Ryan (1999).

Perhaps Roland Suso Richter's Der Tunnel would have been a better choice for the opening night presentation. Shot in German in Prague and at Studio Babelsberg, this story of a famous tunnel escape route under the Berlin Wall was aired on Sat 1 as a television special immediately prior to the Berlinale and given a gala launch as a film production in the Zoo Palast.

\section{Rehearsal for the Oscars}

Once again, the highlights at the 51st Berlinale under Moritz de Hadeln (his last year as Berlinale director) were the Hollywood entries and a roll-call of Oscar-tipped name directors: Steven Soderbergh's Traffic, Philip Kaufman's Quills, Lasse Hallström's Chocolat, Ridley Scott's Hannibal, Spike Lee's Bamboozled, Mike 
Nichols's Wit, Gus van Sant's Finding Forrester, John Boorman's The Tailor of Panama, and Michael Winterbottom's The Claim. Of these, Hannibal received the most pre-festival publicity. Not only does writer Thomas Harris enjoy a large German following, but Jonathan Demme's adaptation of his The Silence of the Lambs -- to which Scott Ridley's Hannibal is now the sequel -- also raised some eyebrows a decade ago at the 1991 Berlinale. Back then, the international jury only saw fit to honour Demme with a share of the Silver Bear for Best Director -- whereupon, a few weeks later, the film was awarded top Oscars in major categories. This time around, its producers made sure that Hannibal, with Anthony Hopkins again as Hannibal Lector and Marianne Moore as Clarice Starling (replacing Jodie Foster), would run out-of-competition with the Berlinale serving only as a commercial launching-pad.

Traffic, the best of the Hollywood entries, is part thriller, part melodrama, part political statement, all the while maneuvering the audience through a labyrinth of three interwoven stories that focus in general on the hard facts of the drug trade and in particular on the impossible mission of protecting the young from dealers on the streets. Soderbergh's finesse of contrasting shooting locations (yellow hues for Mexican scenes, dark blues for American suburbs) with diverging personalities (Michael Douglas as the pompous crackdown judge, Benicio del Toro as the savvy Mexican drug-detective) keeps Traffic moving at such a rapid pace that its two-hours-plus length flies by in a flash.

Although the international jury awarded the Best Actor Silver Bear to Benicio del Toro, Geoffrey Rush as Donatien-Alphonse-François, the Marquis de Sade (1740-1814), in Philip Kaufman's Quills towered over other acting performances at the Berlinale. Moreover, European critics are looking forward to the opportunity to compare Kaufman's Quills with Benoit Jacquot's Sade, a new French production on the life and writings of the notorious marquis. When early in the last century the Surrealists adopted Sade as their patron saint ("the freest spirit who ever lived"), the core of Sade's writings -- sex versus hypocrisy, hedonism over ethics, the erotic defeating the romantic their tenets found expression in the works of Pasolini, Artaud, Mishima, and Peter Weiss. As for Quills, the filmmaker-philosopher has picked up where he left off in Henry and June (1990), a precise and meticulous portrait of another libertarian: Henry Miller.

\section{History Retraced}

History, particularly historical events, continues to fascinate festival audiences. Roger Donaldson's Thirteen Days follows in the vein of Oliver Stone's JFK -- indeed, this compact review of the Cuban Crisis in October of 1962 helps to explain some of the whys and wherefores of the presidential assassination a year later in November of 1963. Wisely Donaldson and screenwriter David Self chose to tell the factual story from the perspective of White House adviser Kenny O'Donnell (Kevin Costner), instead of eulogizing John and Robert Kennedy, although O'Donnell himself was hardly the clairvoyant personality depicted in this fast-moving docu-drama. One scene stands out above the others: when the entire White House staff gather around a TV set to watch the showdown at the UN between Adlai Stevenson and Anatoly Dobrinyn, we follow the mounting drama by intercutting both sides of the action and providing an extra visual link via the broadcasting transfer.

Rachid Bouchareb's Little Senegal (France-Germany-Algeria) is all about history. The title refers to a Senegalese community in West Harlem, visited by a retired old-timer who used to work as a guide in the History of Slavery Museum in Senegal. While searching for a long-lost cousin in Manhattan, the old man discovers to his surprise that segregation among African-Americans is as common as between blacks and whites. By the same coin, Bouchareb hints, Afro-Americans "returning home" to the African continent will probably encounter the same prejudices, experience the same cultural shock, and lose their way in the same labyrinth of social mores and racial preconceptions. The telling moment in the film is when the kindly widower introduces himself to a young black girl in Harlem who stems from the same ethnic roots. "I'm from Senegal," he says. "Why don't you go back there?" she responds.

By contrast, Spike Lee's Bamboozled, subtitled It's Showtime for the Berlinale audience, responds to the question of African roots in a droll, ironic, satirical tone. The setting is one of today's media giants -- given the title "CSN-TV" -- and the manipulator-bamboozler is Pierre Delacroix (Damon Wayans), "a black writerproducer with a very white heart," who has denied his African roots altogether, affects pseudo-European manners, and stages a modern-day minstrel show with black actors in black-face. Is this an indictment of America's lasting taste for black stereotypes, or does it target black entertainers who strip black culture of 
its integrity for shallow financial gain? Hard to say, but probably both. Whatever, Spike Lee's first venture into digital-video-filmmaking might just inspire a wave of black dogma films.

\section{French Cinema Triumphs}

Patrice Chéreau's Intimacy was awarded the Golden Bear. Kerry Fox, the film's sex-obsessed protagonist, received the Silver Bear for Best Actress. And Intimacy was given the Blue Angel Prize for Best European Film. One arresting sequence in the film probes below the surface and defines the erotic liaison for what it really is: loneliness. When Jay (Mark Rylance), who has left wife and children, can no longer contain his curiosity as to who his nameless Wednesday sex-partner really is, he follows Claire (Kerry Fox) to a little suburban theatre, where she is performing in Tennessee Williams's "The Glass Menagerie" -- an appropriate theatrical allusion to her real-life dilemma.

Another French entry was also worthy of award consideration by the international jury. In Catherine Breillat's À ma soeur (why Fat Girl as the English title?) the focus is on the younger "ugly duckling" of two precocious teenaged sisters from an upper-class French family. While on summer holidays at the beach, the girls talk sex and wrestle with the first pangs of a love affair: 15-year-old Elena (Roxane Mesquita) flirts with a boy and goes to bed with him, while 12-year-old Anaïs (Anaïs Reboux) is reduced to a jealous observer. When the mother is informed of the affair, she breaks off the vacation and sets out for home in a rush. The rest runs its course like a Greek tragedy: the mother and Elena are brutally murdered at a rest-stop on the expressway and Anaïs raped by the assailant. A probing film on sex and morality, À ma soeur poses more questions than offering answers.

Before the Berlinale, actress Kerry Fox was less known than writer Hanif Kureishi, the author of the novella upon which Intimacy was based. She was also overlooked by the festival media, whose attention was directed instead towards Charlotte Gainsbourg, the eye-catching, mysterious girl who rides the bumper-cars on a fairgrounds in Patrice Leconte's Felix et Lola, and Juliette Binoche, the pert proprietress of a chocolate shoppe in Lasse Hallström's Chocolat (USA), who received word of her Oscar nomination midway through the Berlinale. A word should be said, too, about another fine acting performance given by Emma Thompson in Mike Nichols's Wit (USA), a HBO screen adaptation of Margaret Edson's play about a woman professor diagnosed with terminal cancer. Here Thompson, a veteran stage actress, seemed to be completely at home in her natural element.

\section{Independents}

Like it or not, digital-video-filmmaking (a contradiction in terms) is here to stay. Lone Scherfig's Italiensk for Bergyndere (Italian for Beginners, Denmark), billed as "Dogma 12" and shot with DV cameras, was written and directed by a filmmaker whose prior work was mostly in telefeatures and the documentary field. This witty, bubbling, hilarious sketch of average people attending an evening Italian class in a Copenhagen neighbourhood comes across as a lively comédie humaine packed with unexpected twists -- for example, the scene in which two women at a funeral discover they are sisters. At times funny, at turns melancholic, yet always tender and human, the film ends on a merry note: when these passing acquaintances in the evening class gradually come to know and like each other, they book a trip together to Italy!

"There's plenty of love in my film," said Lone Scherfig. "Plenty of flirts, sexual innuendo, friendship and family ties, flashes of another quality that could be called the Italian layer of the film -- either that, or something very Danish." And she added: "The dogma approach with hand-held video-cameras allows for plenty of spontaneous improvisation, something not easily accomplished in normal film production." Italian for Beginners, clearly the work of a professional filmmaker with a light hand for slice-of-life situations, was already a runaway hit at the Danish box office when it arrived at the Berlinale to be awarded the Jury Prize, the FIPRESCI (International Critics) Prize, the Ecumenical Prize, and the Berliner Morgenpost Readers's Prize.

Another comédie humaine along the same lines, Filippos Tsitos's My Sweet Home (Germany-Greece) is set in a Berlin bar-restaurant on the eve of a wedding -- with the added twist that both the German bride and the American bridegroom are suddenly getting cold feet. After all, the couple only know each other for a month, and she's a single mother whose nagging mother is entirely against the match. Add to this a cross-cultural mix of nationalities and backgrounds -- one with a psychological hangup, another without the needed resident permit, a third facing a family crisis, a fourth still a slave to his East German past, and so 
on -- and you have a multi-lingual tragicomedy on a live-and-let-live theme, never mind the cruel tricks fate can play.

A recent graduate of the Berlin Film Academy, Filippos Tsitos has won prizes and pleased audiences with a trio of shorts: Charleston (1996), about a grandmother who loves to dance and wants to charleston at her birthday party; Time Flies (1996), an amusing tale of portrait-artists competing for customers on a bridge one summer day in Berlin; and Parlez-moi d'amour (1994), featuring a Greek and a Russian trying to explain to each other in flamboyant lingo exchanges just what "love" is all about. To some extent, Tsitos is still trying to answer that question in his debut feature My Sweet Home.

Listen closely to the soundtrack of My Sweet Home, and you will hear the familiar chords of the Belgradebased No Smoking rock band, founded twenty years ago and known abroad for bass-guitarist Emir Kusturica (a band member since 1986) and drummer Stribor Kusturica (Emir's son, band member since 1994). Balkan punk-jazz-gypsy music being their specialty, No Smoking hit its stride when fans turned up at the Venice festival to applaud the band for its soundtrack to Kusturica's Black Cat, White Cat (1997). Ever since the band has been on tour, accompanied sometimes by film and video cameras, with the results on view at a special screening of Emir Kusturica's Super 8 Stories (Germany-Italy). Asked to cite the band's musical repertoire, Emir described the phenomenon as "an explosive mixture of jazz and gypsy music in which southern Serb trumpets mingle with the melancholy sounds of Asian influences." Kusturica decided to present his rambling, rough-cut documentary in Berlin because, back in 1993, his Arizona Dream was awarded here the Special Jury Prize.

\section{The Light Fantastic}

Tales of myth and magic had their place at the Berlinale. Giuseppe Tornatore's Malèna (Italy), set in wartorn Sicily in the summer of 1942, dips into the same nostalgic bag of memories as did his Cinema Paradiso (1988), this time focusing on the coming-of-age of an adolescent boy in love with a voluptuous young widow. José Luis García's Una historia de entonces (You're the One, Spain), set in a mountain village in 1946, sketches how a woman finds a way out of mourning for a loved one who died in prison by sharing a boy's passion for the cinema and organizing a nativity play to celebrate Christmas. In Lucrecia Martel's debut feature La Ciénaga (The Swamp, Argentina-Spain) an old villa in the swamplands of northwest Argentina hold secrets that will split family relationships down the middle. In Masato Harada's Inugami (Japan), set in a mountain village on the island of Shikoku, the local gods (named in the title) are roused out of their peaceful sleep by the arrival of a new teacher in the village. And in Go Riju's Chloe (Japan) a flower bud discovered on the lung of a young girl requires an operation -- and a water lily is removed!

Magic and mystery are used to particularly good effect in Wojciech Marczewski's Weiser (Poland-SwitzerlandGermany-Denmark). Narrated in flashback to the summer of 1967 -- just prior to the troubled anti-Semitic period in modern Polish history, when Jewish citizens were forced to emigrate abroad -- this is the story of teenagers Pawel and Elke and their friendship with Dawid Weiser, a mysterious Jewish boy with magical powers to ward off evil. Critics may well remember the director's last visit to the Berlinale in February of 1982, just a few weeks after martial law had been declared in Poland by General Jaruzelski. On that occasion, when Marczewski presented Shivers to the audience in the Zoo Palast, his film was recognized as far more than just an open attack on the postwar Stalinist Personality Cult -- and a "Solidarność" banner was unfurled in a show of sympathy. Furthermore, when Shivers was awarded a Jury Prize, Marczewski found himself on the banned list and without work for a decade -- until 1991, when his metaphorical Escape from "Liberty" Cinema (1991), a sketch of Polish provincialism with the focus on a dull-witted movie censor, was programmed in the Certain Regard at Cannes.

\section{Far East Cinema}

What would the Berlinale do without the vital input from the Far East? One of the key films this year came from South Korea: Park Chan-wook's JSA, a political drama set on the border between North and South Korea that unravels slowly as a poignant but dangerous game of friendship between soldiers in opposing ideological armies. Based on Park Sang-yeon's novel DMZ (short for "Demilitarized Zone," the no-man'sland between North and South Korea for the past half-century), Park Chan-wook's JSA (short for "Joint Security Area," as the zone is known to Koreans) had just broken a home box-office attendance record when the news broke that South Korean President Kim Dae-jung was to be awarded the Nobel Peace Prize. 
Part courtroom drama, part forbidden camaraderie between young border guards on both sides, JSA scores as a tightly woven thriller with plot twists that tease and comic moments that entertain all the way down the line. The lead figure, a female Swiss army major of Korean descent, has been sent to Panmunjom to investigate the death of a North Korean border guard, who was apparently shot in the line of duty by a South Korean guard. At first, neither army officers from the South, nor communist officials from the North, will cooperate -- until it's obvious to all that the truth must come out to defuse a potentially explosive international incident. Needless to say, since the North-South conflicts in JSA echoed to some degree the East-West standstill in Germany a decade ago, the film was generally viewed as a welcomed competition entry.

Japanese cinema is experiencing a revival. Go Riju's Chloe -- directed by the same actor who played the killer in the opening sequence of Shinji Aoyama's award-winning Eureka (Cannes 2000) -- is a familiar face at the International Forum of Young Cinema. His experimental features Zazie (1984) and Elephant Song (1994), both programmed in the Forum, led to the making of his feature Berlin (1995). As for the moral message of the lily on the lung, the story is based on a French novel by Boris Vian, a postwar neo-Dadaist. Go feels that both the novel and his film adaptation give some clues to "how we should live."

Similarly, Masato Harada's Inugami, directed by a Japanese filmmaker with a polished professional eye, intrigues as a ghost story thriller. Off to Los Angeles at the age of 24 to work as a critic-journalist, Masato Harada spent the 1970s watching Hollywood genre movies, writing on Howard Hawks, and assisting American directors on Japanese projects (Irving Kershner's The Ninja, 1981), while preparing to make his first feature, a gangster tale. Back in Tokyo, he developed into an auteur with pseudo-Hollywood credentials: Robot War (1889), Kamikaze Taxi (1995), Baunsu koGALS (1997), and Spellbound (1999). Baunsu koGALS, about Japanese teenagers working as call-girls for a night, provoked attacks in the press. Spellbound was praised as a low-budget take-off on Kurosawa's High and Low thriller. And in Inugami, his response to the traditional Japanese ghost-film, villagers on the island of Shikoku are plagued with nightmares while the countenance of a woman living the woods becomes younger at each appearance in the community.

Taiwan director Lin Cheng-sheng's Ai ni ai wo (Betelnut Beauty), set in Taipei in mid-summer, comes across as a poignant fiction-documentary about young people who can't find their way. A young man fresh out of army service doesn't want to return to his former job as a baker (Lin himself is an ex-baker), so he drifts into the illegal traffic of "betelnuts" (a cross between caffeine and marihuana) that's sold to taxi and truck drivers. There he meets a new phenomenon in Taiwan: a "betelnut beauty," or young street-walker in a scanty mini-skirt to attract customers. Before long, they are a couple whose relationship is doomed from the beginning, as they struggle to dodge the gangs, the police, and a pimp having an eye on the girl.

A familiar face at Cannes, Lin's second feature Murmur of Youth (1997) attracted critical attention in the Directors Fortnight by upgrading a previous documentary into an intimate docu-drama about two young girls. Both named Mei-li (meaning "Pretty") ,but coming from different social backgrounds, they while away hours in the box-office of a Taipei cinema in a revealing give-and-take about families and fantasies. His third feature March of Happiness (1999), invited to the Certain Regard, sketched the aspirations of a young couple, an actress and a musician, during the immediate postwar years in a troubled Taiwan. It paved the way for an invitation to the Pusan Project Plan at the 1999 Pusan festival, where Lin pitched Betelnut Beauty and secured support for the project from Taiwan and French coproducers.

Lastly, Wang Xiaoshuai's Shi qi sui de dan che (Beijing Bicycle) (China-France) presents us with an unusual portrait of China and its teaming capital city by a director of the so-called "Sixth Generation." Two teenaged youths -- one from a country village, the other from the urban working-class -- aspire to higher opportunities. The country boy gets a job as a courier, for which he is given a uniform and a high-speed mountain bicycle to be paid for out of his salary. The other, a student at an elite school, badly needs a bicycle to boost his image with classmates, who cruise the neighbourhood on bikes, and to impress a girl. So the bike is stolen -- and the story unravels to reveal much about different social classes in today's China -- from the poor and the upper-crust -- until it ends on a brutal note.

Wang Xiaoshuai is an independent Chinese director to keep an eye on. Of the five feature films to his credit Days (1993) was held back briefly by the censors, while So Close to Paradise (1998) was shelved for three years because it focused on social dilemmas in contemporary China. His second feature, Frozen (1996), 
the story of a performance artist who wants to stage his own suicide as a forceful political statement, was directed under a pseudonym -- and received the Tiger Award at Rotterdam. At his press conference Wang gave no assurance that Beijing Bicycle, a French coproduction, would be readily released in China. Perhaps the Special Jury Prize will help pave the way.

\section{References}

\section{INTERNATIONAL JURY AWARDS}

\section{Golden Bear}

Intimacy (France), Patrice Chéreau

Silver Bear, Grand Jury Prize

Shi qi sui de dan che (Beijing Bicycle, China), Wang Xiaoshuai

Silver Bear, Jury Prize

Italiensk for Begyndere (Italian for Beginners, Denmark), Lone Scherfig

Silver Bear, Best Actress

Kerry Fox, Intimacy (France), Patrice Chéreau

Silver Bear, Best Actor

Benicio del Toro, Traffic (USA), Steven Soderbergh

Silver Bear, Best Director

Lin Cheng-sheng, Ai ni ai wo (Betelnut Beauty, Taiwan-France)

Silver Bear, Individual Contribution

Cinematographer Paúl Pérez Cubero for You're the One (Une historia de entonces, Spain), José Luis Garci

Golden Bear, Short Film

Âme noire (Black Soul, Canada), Martine Chartrand

Silver Bear, Short Film

Jungle Jazz: Public Enemy \#1 (USA), Frank Fitzpatrick

Blue Angel (AGICOA Copyright) Prize for Best European Film

Intimacy (France), Patrice Chéreau

Alfred Bauer Prize for Debut Film

La Ciénaga (The Swamp, Argentina), Lucrecia Martel

OTHER AWARDS

FIPRESCI (International Critics) Awards

Competition: Italiensk for Begyndere (Italian for Beginners, Denmark), Lone Scherfig

Forum: Danach hätte es schön sein müssen (It Should Have Been Nice After That, Germany), Karin Jurschick

Panorama: Maelström (Canada), Denis Villeneuve

Ecumenical Jury Prizes

Competition: Italiensk for Begyndere (Italian for Beginners, Denmark), Lone Scherfig

Special Prize: Blue End (Switzerland), Kaspar Kasics

Forum: Det Nya Landet (The New Land, Sweden), Geir Hansteen Jörgensen

Peace Film Prize

Vivre après - Paroles de femmes (Living Afterwards - Words of Women, France), Laurent Bécue-Renard

Wolfgang Staudte Prize - Forum

Love/Juice (Japan), Kaze Shindo 
Don Quixote Prize (International Federation of Film Societies)

Forum: Karunam (Pathos, India), Jayaraaj

CICAE Prize (International Confederation of Art Cinemas)

Panorama: Late Night Shopping (UK), Saul Metzstein

Forum: Love/Juice (Japan), Kaze Shindo

Guild of German Art House Cinemas Prize

Finding Forrester (USA), Gus van Sant

Caligari Prize (German Association of Communal Film Work)

Crónica de un sesayuno (A Breakfast Chronicle, Mexico), Benjamin Cann

Netpac Prize - Network for Promotion of Asian Cinema - Forum

Forum: Booye kafoor, atre yas (Smell of Camphor, Fragrance of Jasmine, Iran), Bahman Farmanara

Special Mention: Ben khong chong (Wharf of Widows, Vietnam), Luu Trong Ninh

Readers' Prize of Berliner Morgenpost

Italiensk for Begyndere (Italian for Beginners, Denmark), Lone Scherfig

Readers' Prize of Berliner Zeitung

Werkmeister Harmóniák (Werkmeister Harmonies, Hungary), Béla Tarr

International Jury, Children's Film Festival

Nagisa (Japan), Mararu Konuma

Short: Hooves of Fire (UK), Richard Goleszowski

Crystal Bear, Young People's Jury, Children's Film Festival

There's Only One Jimmy Grimble (UK), John Hay

Short: Hooves of Fire (UK), Richard Goleszowski

\section{Author Information}

Ron HOLLOWAY (1933-2009) was an American critic, film historian, filmmaker and correspondent who adopted Europe as his home in the early fifties and spent much of his life in Berlin. He was an expert on the study of German cinema and against all odds produced, with his wife Dorothea, the journal German Film, keeping us up-to-date with the work of directors, producers and writers and the showing of German films around the world.

In 2007, Ron Holloway and his wife were awarded the Berlinale Camera Award. Ron also received the Bundesverdienstkreuz (German Cross of Merit), Polish Rings, Cannes Gold Medaille, the American Cinema Foundation Award, the Diploma for Support of Russian Cinema and an honorary award from the German Film Critics' Association.

Ron was also a valued contributor to Kinema for the past fifteen years. 